\title{
A review of causes of variation order in the construction of terrace housing projects in Malaysia
}

\author{
Noraziah Mohammad*, and Zabidi Hamzah \\ Department of Architecture, Faculty of Engineering and Built Environment, National University of \\ Malaysia (UKM), Bangi, Selangor, Malaysia
}

\begin{abstract}
Variation order refers to any changes from the scope, plan, specification or contract document in the construction project. This changes of work is a common problem in construction projects in Malaysia. It is inevitable in any construction project and this problem can become more serious when variation order causes work progress to be impaired as a results it increased the construction time and cost that affects the construction industry in Malaysia. This paper critically review the causes of variation order in the construction industry on the double-storey terrace housing project in Malaysia. The discussions began with the construction industry in Malaysia and then related parties involved in the construction industry. The extensive local and abroad literature review on the definitions of variation order and analysis of past studies conducted on variation order and the previous study of the prediction model of variation. The extensive literature on variation order in the construction of building project may help to improve the performance in term of time, cost and quality of the construction of building projects in Malaysia.
\end{abstract}

\section{Introduction}

Variation order refers to any changes to the scope of work, planning, and specification or contract documents in a construction project. There are many interpretations of variation order from the literature reviews. [1] states that in a tender and building contract, the term variation is any changes to the works under the supervision of an architect as the contract administrator on behalf of the client or employer. On the other hand, [2] interprets the variation in works as modifications to the scope and schedule agreed. Generally, it is changes or any modification to the contract awarded to a contractor as a guide to the client or client's representative. This include variations to the planning, specification, or any of the contract documents. According to [3] and [4] from the construction context, variation order is also known as variations. Any variation instruction is an official document that is

\footnotetext{
*Corresponding author: noraziahmohammad@ukm.edu.my
} 
used to modify the original contract given to the contractor by the client or client's reptresentative and become part of the project documents. Increase in variation orders in a project may resulted in additional time and cost. When variation order is issued, contractors are inclined to charge at a higher rate for the work changes, thus affecting the client's budget. The change of work is a common problem in construction projects in Malaysia. This change of work is inevitable in any construction project and this problem can become more serious when variation order causes work progress to be impaired as a results of the increased in the construction time and cost that affects the construction industry in Malaysia.

\section{Research Objectives}

The main objectives of this research are as follows:

2.1 Comprehensive literature review relating to variation order in the construction industry carried out by previous researcher.

2.2 Identifying the causes of variation order in the construction project.

2.3 Identifying the parties contributing to the variation order.

\section{Literature Review}

Even though the project planning is properly implemented, the possibility of changes happening cannot be dismissed due to various factors [3]. There are various causes why changes of variation order taking place in a construction project, whether identifiable or not.

\subsection{The causes of variation works}

From the literature review, it is found that there are 18 main causes of the variation works identified by most researches ([5],[6],[2],[7],[3],[8],[9],[10],[11],[12], [13], [14], [15],[16] and [17]). The causes of variation order are described as follows:

Changes of scope by client: Changes to planning or the project scope is one of the main causes in the construction project [18]. This is due to improper planning at the project definition or due to lack of collaboration by the owner in the design phase [9]. [19], in his research identified the effects of variation works in the sport facilities in Egypt and found that additional scope of work by the client is one of the factor that give a big impact during the project implementation.

Owner's financial problems: The owner's financial problems can effect the quality and progress of the project [9] and [3]. This problem often brings changes to the schedule and work specification and subsequently the construction quality.[11] have studied the causes and effects of variation works in road construction projects in Iran and found that variation works are caused by changes in the scope of work by the employer, mistakes and outdated design as wll as finacial problem of the owner.

Inadequate project objectives: Inadequate project objectives can cause variation in the construction projects. According to [20], it limits the designers with the appropriate design that can result in variation works in the later stages of the construction process.

Replacement of materials or procedures: Replacement of materials or work procedure can cause changes during the construction phase. Replacement of work procedure also involve changes to the work method ) [21]. 
Impediment to prompt decision-making process: Prompt decision-making is an important factor in the success of a project [11]. Failure to make a quick decision can cause the delay and the needs for work changes due to raise in cost.

Obstinate nature of owner: A building project is the outcome of work collaboration of professionals that are involve in the various phases of a construction project [9].The owner's attitude with individual opinion without considering the professional involve can cause the changes in work in the last stage of a project.

Change in specifications by the owner: Changes in specification by owners are common phenomena in construction projects due to inadequate project objectives [3]. If this change is on the client's requirement, this leads to a change in the construction phase

Change in design by the consultant:A change in design for improvement by the consultant is a norm in contemporary professional practice [9]. Changes in design are frequent in projects where construction starts before the design is finalized [2]. Such changes can affect the project in various ways depending on the timing of the change.

Errors and omissions in design: Errors and omissions in design are a significant cause of project delays [9]. Dependent upon the timing of the errors in the project, delays and variations may occur [13], work changes are a key issue in the construction industry in Ghana and are largely due to client design changes.

Conflicts among contract documents: Conflict between contract documents can result in misinterpretation of the actual requirement of a project [22]. It is essential that contract documents are clear and precise. Inadequate information in contract documents may result in delays in project completion or cause changes in costs.

Technology changes: Changes in technology could potentially result in variations on a project. . Project planning should be flexible for accommodating new beneficial variations [23]. Emergence of new technology can affect construction methods and processes.

Value engineering: Value engineering should ideally be carried out during the design phase [24]. Value engineering carried out during the construction phase can become an extremely costly exercise and may result in variations.

Lack of coordination: A lack of coordination between parties may cause major variations with adverse impact on the project [9], leading to dissatisfaction of the owner, reconstruction work and work changes.

Design complexity: Complex designs require unique skills and construction methods [9]. Complexity affects the flow of construction activities, whereas simpler and linear construction works are relatively easy to handle [2]. This would suggest that the more complex a construction design is, the more there is a chance that variations may occur.

Inadequate working drawing details: To convey a complete concept of the project design, the working drawings must be clear and concise [25]. Insufficient working drawing details can result in misinterpretation of the actual requirements for the project [6], causing variations in the project.

Consultants' lack of required data: A lack of data can result in misinterpretation of the actual requirements of a project [26]. If there is not enough data available to the consultant then the design is based more on the consultants' own perception of the requirements of the project. Should these perceptions be wrong, then variations will occur.

Poor knowledge of available materials and equipment: Knowledge of available materials and equipment is an important factor for developing a comprehensive design [25]. If the consultant has a poor knowledge of available materials or equipment that can be used in the construction process, variations are more likely to occur during the construction phase.

Ambiguous design details: A clearer design tends to be comprehended more readily. Ambiguity in design may cause misinterpretations and the need for rework leading to delay and increased cost. [27] studied factors influencing thirty-one high-rise buildings in 
Indonesia and found that design changes were one of the most important factors that led to the increase in time and cost. Summary of the major causes of variation order based on the 18 factors identified by the results of the literature review are shown in table 1 .

\subsection{Parties that contribute to variation order}

The major contributors to variation order have been grouped under four categories which is client, consultant, contractor and other parties [8], [28], [29] and [30]. The connection between the parties who contribute to the variation order will be discussed as below:

Variations order caused by owner: The causes of change in road construction in Iran are due to changes in scope by employers, errors and omissions in design and financial problems by owners [11] and most of the causes of change of work are change of design by clients and details of work drawings are not complete [13].

Variations order caused by consultant : [31] recommends consultants to understand the scope and project requirements. In general, the role of the consultant is to advise clients on technical matters, laws and financial aspects. The following are the variation order associated with the consultants which is design mistakes and changes, the failure to determine the best alternative design for the project in the feasibility study [32].

Variations order caused by contractor: [33] suggesting for each project, the parties concerned should be concerned with possible problems. It is the contractor's responsibility to advise the consultant to issue a change of working instructions when there is a technical problem in the project.

Variations order caused by others: Conditions beyond the control of other parties that are not in the contract, may cause changes in the work. Among them are weather conditions, security, changes in government regulations, changes in economic conditions, sociocultural factors and unforeseen problems [28]. The summary of the parties contributing to the variations order identified as a result of the literature review is shown below table 2 .

Table 1. Summary of literature review of the causes of variation order.

\begin{tabular}{|c|c|c|c|c|c|c|c|c|c|c|c|c|c|c|c|c|c|c|}
\hline $\begin{array}{l}\text { CAUSES OF } \\
\text { VARIATION } \\
\text { ORDER AND } \\
\text { AUTHOR }\end{array}$ & 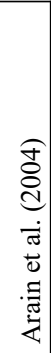 & 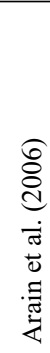 & 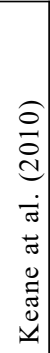 & 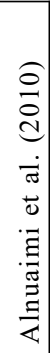 & 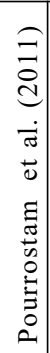 & 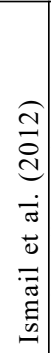 & 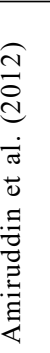 & 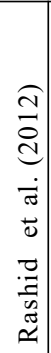 & 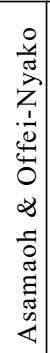 & 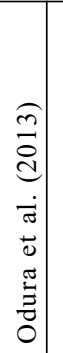 & 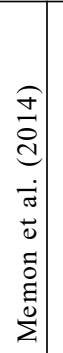 & 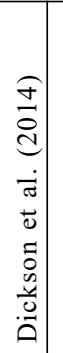 & 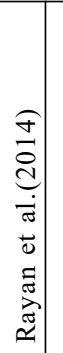 & 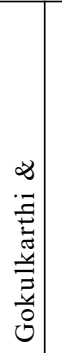 & 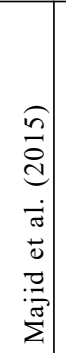 & 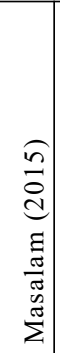 & 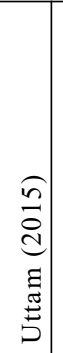 & 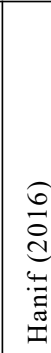 \\
\hline $\begin{array}{l}\text { Changes of scope } \\
\text { by client }\end{array}$ & $\sqrt{ }$ & $\sqrt{ }$ & $\sqrt{ }$ & $\sqrt{ }$ & $\sqrt{ }$ & $\sqrt{ }$ & $\sqrt{ }$ & $\sqrt{ }$ & $\sqrt{ }$ & $\sqrt{ }$ & $\sqrt{ }$ & $\sqrt{ }$ & $\sqrt{ }$ & $\sqrt{ }$ & $\sqrt{ }$ & $\sqrt{ }$ & $\sqrt{ }$ & $\sqrt{ }$ \\
\hline $\begin{array}{l}\text { Owner's financial } \\
\text { problems }\end{array}$ & & $\sqrt{ }$ & $\sqrt{ }$ & & & $\sqrt{ }$ & $\sqrt{ }$ & $\sqrt{ }$ & $\sqrt{ }$ & & $\sqrt{ }$ & & & $\sqrt{ }$ & $\sqrt{ }$ & $\sqrt{ }$ & & $\sqrt{ }$ \\
\hline $\begin{array}{l}\text { Inadequate project } \\
\text { objectives }\end{array}$ & $\sqrt{ }$ & $\sqrt{ }$ & $\sqrt{ }$ & & & & $\sqrt{ }$ & & $\sqrt{ }$ & & $\sqrt{ }$ & & & $\sqrt{ }$ & & & $\sqrt{ }$ & $\sqrt{ }$ \\
\hline $\begin{array}{l}\text { Replacement of } \\
\text { materials or } \\
\text { procedures }\end{array}$ & & $\sqrt{ }$ & $\sqrt{ }$ & & $\sqrt{ }$ & $\sqrt{ }$ & $\sqrt{ }$ & & & & & & $\sqrt{ }$ & $\sqrt{ }$ & & & $\sqrt{ }$ & $\sqrt{ }$ \\
\hline $\begin{array}{l}\text { Impediment to } \\
\text { prompt decision- }\end{array}$ & $\sqrt{ }$ & $\sqrt{ }$ & $\sqrt{ }$ & $\sqrt{ }$ & & & $\sqrt{ }$ & & $\sqrt{ }$ & & $\sqrt{ }$ & & & & & $\sqrt{ }$ & $\sqrt{ }$ & \\
\hline
\end{tabular}




\begin{tabular}{|c|c|c|c|c|c|c|c|c|c|c|c|c|c|c|c|c|c|c|}
\hline making process & & & & & & & & & & & & & & & & & & \\
\hline $\begin{array}{l}\text { Obstinate nature of } \\
\text { owner }\end{array}$ & $\sqrt{ }$ & $\sqrt{ }$ & $\sqrt{ }$ & & $\sqrt{ }$ & & $\sqrt{ }$ & $\sqrt{ }$ & & & $\sqrt{ }$ & & & & & & $\sqrt{ }$ & \\
\hline $\begin{array}{l}\text { Change in } \\
\text { specifications by } \\
\text { the owner. }\end{array}$ & $\sqrt{ }$ & $\sqrt{ }$ & $\sqrt{ }$ & & & & $\sqrt{ }$ & & $\sqrt{ }$ & & $\sqrt{ }$ & & & & & & & $\sqrt{ }$ \\
\hline $\begin{array}{l}\text { Change in design } \\
\text { by the consultant }\end{array}$ & $\sqrt{ }$ & $\sqrt{ }$ & $\sqrt{ }$ & $\sqrt{ }$ & & & $\sqrt{ }$ & $\sqrt{ }$ & & & $\sqrt{ }$ & $\sqrt{ }$ & $\sqrt{ }$ & $\sqrt{ }$ & $\sqrt{ }$ & & $\sqrt{ }$ & \\
\hline $\begin{array}{l}\text { Errors and } \\
\text { omissions in } \\
\text { design }\end{array}$ & $\sqrt{ }$ & $\sqrt{ }$ & $\sqrt{ }$ & $\sqrt{ }$ & & $\sqrt{ }$ & $\sqrt{ }$ & $\sqrt{ }$ & & & & $\sqrt{ }$ & $\sqrt{ }$ & $\sqrt{ }$ & & & & $\sqrt{ }$ \\
\hline $\begin{array}{l}\text { Conflicts among } \\
\text { contract documents }\end{array}$ & & $\sqrt{ }$ & $\sqrt{ }$ & & & & $\sqrt{ }$ & & $\sqrt{ }$ & & $\sqrt{ }$ & $\sqrt{ }$ & & $\sqrt{ }$ & $\sqrt{ }$ & $\sqrt{ }$ & & $\sqrt{ }$ \\
\hline $\begin{array}{l}\text { Technology } \\
\text { changes }\end{array}$ & & $\sqrt{ }$ & $\sqrt{ }$ & & $\sqrt{ }$ & & $\sqrt{ }$ & & $\sqrt{ }$ & & & & & $\sqrt{ }$ & & $\sqrt{ }$ & & \\
\hline Value engineering & $\sqrt{ }$ & $\sqrt{ }$ & $\sqrt{ }$ & & & $\sqrt{ }$ & $\sqrt{ }$ & $\sqrt{ }$ & & & & & & $\sqrt{ }$ & & & & \\
\hline $\begin{array}{l}\text { Lack of } \\
\text { coordination }\end{array}$ & $\sqrt{ }$ & $\sqrt{ }$ & $\sqrt{ }$ & & & & $\sqrt{ }$ & & $\sqrt{ }$ & & & $\sqrt{ }$ & & & $\sqrt{ }$ & $\sqrt{ }$ & & \\
\hline Design complexity & $\sqrt{ }$ & $\sqrt{ }$ & $\sqrt{ }$ & & & & $\sqrt{ }$ & & $\sqrt{ }$ & & $\sqrt{ }$ & & & & & & & $\sqrt{ }$ \\
\hline $\begin{array}{l}\text { Inadequate } \\
\text { working drawing } \\
\text { details }\end{array}$ & $\sqrt{ }$ & $\sqrt{ }$ & $\sqrt{ }$ & & & & $\sqrt{ }$ & & $\sqrt{ }$ & & $\sqrt{ }$ & & & & & $\sqrt{ }$ & $\sqrt{ }$ & \\
\hline $\begin{array}{l}\text { Poor knowledge of } \\
\text { available materials } \\
\text { and equipment }\end{array}$ & $\sqrt{ }$ & $\sqrt{ }$ & $\sqrt{ }$ & & & & & & $\sqrt{ }$ & & & & & $\sqrt{ }$ & & & & \\
\hline $\begin{array}{l}\text { Consultants' lack } \\
\text { of required data }\end{array}$ & $\sqrt{ }$ & $\sqrt{ }$ & $\sqrt{ }$ & & & & & $\sqrt{ }$ & & & & & & & $\sqrt{ }$ & $\sqrt{ }$ & $\sqrt{ }$ & $\sqrt{ }$ \\
\hline $\begin{array}{l}\text { Insufficient details } \\
\text { in the contract } \\
\text { documents }\end{array}$ & $\sqrt{ }$ & $\sqrt{ }$ & $\sqrt{ }$ & & & & $\sqrt{ }$ & $\sqrt{ }$ & & $\sqrt{ }$ & & & & & & $\sqrt{ }$ & $\sqrt{ }$ & \\
\hline
\end{tabular}

Table 2. Summary of literature review of parties contributing to variations order.

\begin{tabular}{|c|c|c|c|c|c|c|c|c|c|c|c|c|c|c|c|c|}
\hline $\begin{array}{l}\text { PARTIES } \\
\text { CONTRIBUTI } \\
\text { NG TO } \\
\text { VARIATION } \\
\text { ORDER AND } \\
\text { AUTHOR }\end{array}$ & 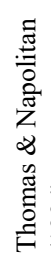 & 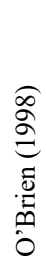 & $\begin{array}{l}\text { } \\
2 \\
\stackrel{2}{=} \\
\frac{\pi}{\pi} \\
\frac{0}{0} \\
0 \\
0 \\
0\end{array}$ & 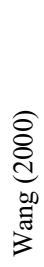 & 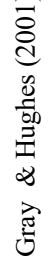 & 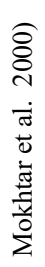 & 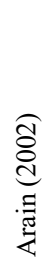 & 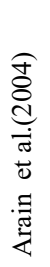 & 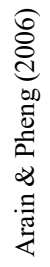 & 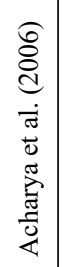 & 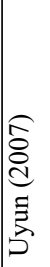 & 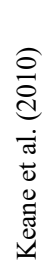 & 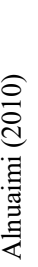 & 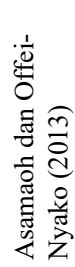 & 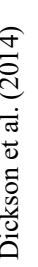 & 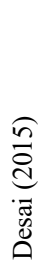 \\
\hline Owner & $\sqrt{ }$ & $\sqrt{ }$ & $\sqrt{ }$ & $\sqrt{ }$ & $\sqrt{ }$ & & $\sqrt{ }$ & $\sqrt{ }$ & $\sqrt{ }$ & & $\sqrt{ }$ & $\sqrt{ }$ & $\sqrt{ }$ & $\sqrt{ }$ & $\sqrt{ }$ & $\sqrt{ }$ \\
\hline Consultant & $\sqrt{ }$ & $\sqrt{ }$ & $\sqrt{ }$ & $\sqrt{ }$ & & $\sqrt{ }$ & & $\sqrt{ }$ & $\sqrt{ }$ & $\sqrt{ }$ & & $\sqrt{ }$ & $\sqrt{ }$ & & $\sqrt{ }$ & $\sqrt{ }$ \\
\hline Contractor & $\sqrt{ }$ & $\sqrt{ }$ & $\sqrt{ }$ & $\sqrt{ }$ & & & $\sqrt{ }$ & $\sqrt{ }$ & $\sqrt{ }$ & & & & & & $\sqrt{ }$ & $\sqrt{ }$ \\
\hline
\end{tabular}




\begin{tabular}{|l|l|l|l|l|l|l|l|l|l|l|l|l|l|l|l|l|l|}
\hline Others & $\sqrt{ }$ & $\sqrt{ }$ & & $\sqrt{ }$ & & & & $\sqrt{ }$ & $\sqrt{ }$ & & & & & & $\sqrt{ }$ & $\sqrt{ }$ \\
\hline
\end{tabular}

\section{Conclusion}

The literature review shows that major causes of the variation orders are due to changes of scope by client. Thus, the main contributer to the variation order are from the client. The finding from the literature studies can be used as reference in reducing the variation order in the construction of terrace housing projects in Malaysia.

\section{Acknowledgment}

The authors would like to thank the Research Incentive Grant research fund (GGP-2017082) under the Center for Research and Instrumentation Management, National University of Malaysia (UKM) who have been supportive of this study.

\section{References}

1. Harbans Singh K.S. 2003. Enginerring and Construction Contracts Management. Post-Commencement Practise. Ed. ke-2. Malaysia: Penerbit LexisNexis, A Devision of Reed Elsevier (Singpore) Pte Ltd.: 423-555.

2. Fisk, E.R. 2013. Construction Project Administration, edisi kesepuluh. Prentice Hall, Upper Saddle River, New Jersey, United Stated.

3. O'Brien J.J. 1998. Construction Change Orders. McGraw-Hill, New York.

4. Arain, F.M., \& Pheng, L.S. (2005). The potential effects of variation orders on institutional buildings projects. Facilities. 23(11/12): 496-510.

5. Thomas, H.R., \& Napolitan,C.L. 1995. Quantitave effects of construction changes on labor productivity. The Journal of Construction Engineering and Management-ASCE. September, 121(3): 290-296.

6. Clough R.H., \& Sears G.A 1994. Construction Contracting, edisi keenam. John Wiley and Sons Inc., New York.

7. Mokhtar, A., Bedard, C., \& Fazio, P. 2000. and scheduling of interrelated design changes. J. Archit. Eng. ASCE, 6(2): 66-75.

8. Gray, C, \& W. Hughes. 2001. Building Design Management. Butterworth Heinemann, Oxford, UK.

9. Arain, F.M., Assaf, A, S., \& Low, S.P. 2004. Causes of discrepancies between design and construction. Architectural Science Review. 47(3): 237-249.

10. Pourrostam, T., Ismail, A., \& Mansournejad, M. 2011. Identification and Evaluation of Causes and Effects of Change Orders in Building Construction Projects. Applied Mechanics and Materials 94-96: 2261-2264. 
11. Ismail, A., Pourrostam, T., Soleymanzadeh, A., \& Ghouyounchizad, M. 2012. Factors causing variation orders and their effects in roadway construction projects. Research Journal of Applied Sciences, Engineering and Technology. 4(23): 4969-4972.

12. Rashid, K.A. 2002. Construction Procurement in Malaysia, Process and Systems, Constraints and Strategies. Gombak: IIUM Press. First Edit.: 1-191.

13. Asamaoh, R.O., \& Offei-Nyako, K. 2013. Variation Determinants in Building Construction: Ghanaian Professionals Perspective. Korea Institute of construction Engineering and Management (KICEM), Journal of Construction Engineering and Project Management 3(4): 20-25.

14. Memon, A.H., Rahman, I,A, \& Abul Hasan, M.F. 2014. Significant causes and effects of variation orders in construction projects. Research Journal of Applied Sciences, Engineering and Technology. 7(21): 4494-4502

15. Gokulkarthi, M.,\& Gowrishankar, K.S. 2015. A Study On Impacts Of Change Order In Construction Projects. International Journal of Science and Engineering Research (IJ0SER) 3(4): $32215687-32215693$

16. Msallam, M., Abojaradeh, M., Jrew, B., \& Zak, I. 2015. Controlling Of Variation Orders in Highway Projects in Jordan. Journal of Engineering and Architecture 3(2): 95-104

17. Hanif, H., Khurshid, M.B., Nauman, S., \& Lindhard, S. 2016. Impact of variation orders on time and cost in mega hydropower projects of Pakistan. Journal of Construction in Developing Countries. Penerbit Universiti Sains Malaysia.: Pg. 1-20

18. (CII) Construction Industry Institute. 1990b. Scope definition and control. Publication 6-2, CII, The University of Texas at Austin, Austin, Tex

19. Rashid, I. A., Mohamed, A. E-M., \& Mohammed, E. A-H. 2012. The Impact of Change Orders on construction projects Sports Facilities Case Study. Journal of American Science. 8(8): 628-631

20. Ibbs, W. \& Allen, W. E. 1995. Quantitative impacts of project change. Source Document 108, Construction Industry Institute, University of Texas at Austin, Austin, Tex

21. Chappell, D., \& Willis, A. 2005. The Architect in practice. Edisi kesembilan, Blackwell Science, Oxford, U.K.

22. (CII) Construction Industry Institute. 1986. Constructability: A Primer. Construction Industry Institute, The University of Texas at Austin, TX

23. (CII) Construction Industry Institute. 1994b. Project change management. University of Texas at Austin, Austin, Tex

24. Dell'Isola, A. J. 1982. Value engineering in the construction industry. 3rd Ed., Van Nostrand Reinhold, New York

25. Geok, O. S. 2002. Causes and improvement for quality problems in design and build projects. Unpublished B.Sc. thesis, National University of Singapore, Singapore. 
26. Arain, F.M. 2002. Design-construction interface dissonances. Thesis, King Fahd University of Petroleum and Minerals, Dhahran, Saudi Arabia

27. Kaming, P.F., Olomolaiye, P.O., Holt, G.D., \& Harris, F.C. 1997. Factors influencing construction time and cost overruns on high rise projects in Indonesia. Construction Management and Economics. 15(1):83-94

28. Arain, F.M., \& Pheng, L.S. 2006. Developers' views of potential causes of variation orders for institutional buildings in Singapore. Architectural Science Review. 49(1): $59-74$.

29. Dickson, O.D., Gerryshom, M., \& Wanyona, G. 2014. Factors Contributing to Variations Construction Projects in Kenya. International Journal of Social Science and Enterpreneurship. 1(13):1-11

30. Desai, J.N., Pitroda, J., \& Bhavsar, J.J. 2015. A Review on Change Order and Assessing Causes Affecting Change Order in Construction. Journal of International Academic Research for Multidisciplinary. 2(12) January 2015: 152-162

31. Acharya, N.K., Lee, Y.D., \& Im, H.M. 2006. Design Errors: Tragic for the Clients. Journal of Construction Research. 7(1/2): 177-190.

32. Al-nuaimi, A.S., Taha, R., Al Mohsin, M., \& Al-Harthi, A.S. 2010. Causes, effects, benefits and remedies of change orders on public construction project in Oman. Journal of Construction Engineering and Management. 136(5): 615-622.

33. Levy, S.M. 2002. Project Management in Construction, 4th Ed. Columbus: McGrawHill 